\title{
Indigenous Land Management Practices and Land Cover Change in Akwa Ibom State, Nigeria
}

\author{
Jacob Atser1, Ekong Faith'1, Uwem Ituen'2, Ekpa James ${ }^{1}$ \\ ${ }^{1}$ Department of Urban and Regional Planning, University of Uyo, Uyo, Nigeria \\ ${ }^{2}$ Department of Geography, University of Uyo, Uyo, Nigeria \\ Email: jacobatser@yahoo.com
}

Received 22 September 2014; revised 15 October 2014; accepted 7 November 2014

Copyright (C) 2014 by authors and Scientific Research Publishing Inc.

This work is licensed under the Creative Commons Attribution International License (CC BY). http://creativecommons.org/licenses/by/4.0/

(c) (i) 0 pen Access

\section{Abstract}

This work sought and identified the different types of land covers; detected the changes in land cover and examined the driving forces of such changes in Ibiono Ibom Local Government Area of Akwa Ibom State, Nigeria. Satellite images data of the area for 1986 and 2006 were collected for analysis. Household level social survey was conducted to generate data on the socio-economic variables. The images were subjected to principal component analysis to reduce and compress the data while the supervised image classification algorithm was applied to process the images into different land cover classes. The change detection algorithm in Erdas imagines was applied to measure and calculate the land cover change of the area. The result of the social survey revealed that $58 \%$ of the occupation was land based while in terms of yearly income, 65 percent earned less than $\$ 300$ (\#48000). The change detection carried out revealed an increase in areas of secondary forest while bush fallow recorded a reduction up to 34.02 hectares $(56.55 \%)$ within the study period. Socio-economic variables of poor income and mode of land preparation for farming were the major drivers of change. Based on the findings, it is recommended that the slash and burn mode of land preparation be discouraged.

\section{Keywords}

Indigenous Land Use Practices, Land Cover Change, Akwa Ibom State, Nigeria

\section{Introduction}

Nature has provided some resources such as air, food, water, plants, animals and energy that could provide for

How to cite this paper: Atser, J., Faith, E., Ituen, U. and James, E. (2014) Indigenous Land Management Practices and Land Cover Change in Akwa Ibom State, Nigeria. Journal of Environmental Protection, 5, 1541-1552. 
the sustenance of the earth. These resources interact with themselves and with one another thus keeping the environment often in a state of balance. In several areas the ecosystem is being depleted by the activities of human on a daily basis. The utilization of natural resources by man has brought about economic implications of depletion such as neglect of future generations, incorrect price predictions, risk aversion, ownership uncertainty, monopoly, the distribution of benefits and taxation on certain natural resources. These depletion problems also include constraints on supply and demand variables, exploitations of various unconventional sources, pollution, monopolization of resources, influence of technology and promotion of systematic exploitation [1]. The land cover represents an enormous valuable resource in terms of the diverse economic products and environmental services it provides. The lives of many people depend on the land cover and its resources [2]. It was observed that land cover including forests is socially, economically and environmentally important, especially tropical forests, which contains at least two-third of the world's living organisms. Land resources play important roles in the economies of many countries; however, it appears that land resources are at a great risk because of severe exploitation. The uncontrolled conversion of forests into other land cover types and uses is an internationally recognized problem. Trees are seen as obstacle to progress and their removal viewed as the first stage in development. These similar observations had earlier been made by [3]-[5]. It has been observed that of all the environmental concerns facing developing nations in the humid tropics, large-scale land cover has most certainly attracted world attention, and it is one of the most serious environmental problems facing Nigeria as a nation today.

Information on land use and land cover is very important in the understanding of both the past, present and future human interactions with the environment. These interactions often result in alteration of the nature of the land cover [1]. [6] Have noted that human activities have directly altered between one-third and half of the earth's surface. Moreover, the impacts of such interactions can be better understood when the current status of the land cover is known. However, in Nigeria, all land development programmes and projects have evolved without an appreciation of the value of land use and land cover information [7]. Consequently, planners plan without facts of what covers where, thereby resulting in uncoordinated development. As land and land related resources are continually being used, little or no attention is paid to the possible changes that may occur. The driving forces of such land cover change will be useful in understanding the past, present and projecting into the future with the aim of taking land allocation decisions which will eventually increase trade-offs on land [8]. In a study on spatio-temporal patterns and driving forces of urban land expansion identified demographic changes, social and economic development, the transition of land use regulation, geophysical differentiation and local policy as drivers of land use change. In an earlier work, [9] observed that land use and its possible changes are usually more of a reflection of socio-economic developments in society than of differences in soil suitability for different forms of land use and land cover.

FAO [10] observed that Nigeria has the world's highest deforestation rate of primary forests and has lost half of its primary forests in the last twenty years through logging, subsistence agriculture and collection of fuel woods. Bush burning, subsistence farming, timber logging, fuel wood, general pressures from increasing population due to urbanization have helped to accelerate the rate of deforestation [11]-[13]. In Akwa Ibom State, the forests at Uwet Odot, Obot Ndom and the Stubbs Creek have suffered from mismanagement [14] while other forests have been reduced to farmlands [15]. The yearly use of land and land resources has high propensity to alter the vegetation, soil characteristics, the terrain and other components of the environment. This alteration quite often assumes the forms of land cover conversion and modification. Land cover change leads to change in land use, and is therefore affected by socio-economic indicators such as rural income, agricultural productivity, wealth and education [16].

In the rural areas of Akwa Ibom State, yearly use of the land with no attention to sound land management practices to compensate for any form of change, or perhaps degradation that might have occurred over time may permanently limit the ability of such land area to continue to yield the much needed productivity given such usage. Although it is obvious that the land cover has changed, nothing is being done to identify and scientifically investigate the important driving forces of such changes. Land is a multipurpose environment and change may be complex and gradual due to the driving forces as well as the interplay of such forces. This implies that any change as a result of different uses may elude the understanding of the farmers and therefore not perceived until serious degradation sets in. Against the above background, the objective of this work is to investigate the rate, magnitude and pattern of land cover change in the study area as well as the direct and underlying causes of such change. A better understanding of these changes and the important drivers over time can enable planners and 
other stakeholders at various levels to design and implement policy interventions which stimulate benefits and counteract negative consequences of land use change by considering the trade-offs among economic, environmental and social objectives in the process of sustainable rural development.

\section{Study Area and Method}

The study area is Ibiono Ibom Local Government Area of Akwa Ibom State, Nigeria. The choice of the area was informed by its tropical rainforest character. It lies between latitudes $4^{\circ} 57^{\prime} \mathrm{N}$ and $5^{\circ} 18^{\prime} \mathrm{N}$ and longitude $7^{\circ} 49^{\prime} \mathrm{E}$ and $7^{\circ} 58^{\prime} \mathrm{E}$. It is in the coastal zone of Southeastern part of Nigeria. Ibiono Ibom Local Government Area has a total landmass of 2761.76 square kilometers comprising 200 villages. Ibiono Ibom Local Government Area is located in the tropical rain forest zone of Nigeria. It however has the fresh water swamp grassland in the northern part. It has tall and woody trees with evergreen leaves all year round. The high temperature, heavy rainfall and high relative humidity favour plant growth. These factors, coupled with the clayey-loamy soil, favour the growth of luxuriant trees in the area. The area belongs to the oil palm belt. It is noteworthy to mention that the rainforest of the area has degenerated into secondary forest re-growth. The secondary forest re-growth of various ages is seriously affected by bush clearing and burning and lumbering. The clearing and burning of the secondary re-growth have damaging effects on the soil condition with resultant gully erosion activities.

A wide range of data sets from both secondary and primary sources were collected and utilized in this work. This includes remote sensing data and socio-economic data. Remote sensing data were acquired from the United States Geological Survey (USGS) using Landsat TM and ETM+ images captured in December 1986 and January 2006. Each had a spatial resolution of approximately $28.5 \mathrm{~m}^{2}$. The year 1986 was selected as the base year because of the scarcity of available images taken before 1986. An existing land use/cover map of the area was also acquired from the Cross River Basin Development Authority (CRBDA). This was used as ancillary data for accuracy assessment of the 1986 classified image. Large-scale aerial photographs of 2002 were also acquired from Akwa Ibom State Ministry of Lands and Housing. These were used to assist in the selection of training areas. They were also used in the accuracy assessment of the 2006 classified image. In this kind of study, spatial sampling procedure would have been more appropriate, but in view of the fact that the locations of most villages were not previously mapped prior to the actual fieldwork, probability sampling techniques were relied upon. This was made possible as the sampling frame containing all the villages was constructed from the 1991 population census records and a table of random numbers used. This proved very reliable as all the villages in the study area were included in the sampling process. More so, this was used in acquiring ground truth data for land use validation. A household survey was conducted using structured questionnaire and interviews with the farmers and community leaders. This provided primary data on socio-economic conditions, agricultural practices and land management options in the rural areas. This work made use of the land use/cover classification scheme adopted by the Cross River Basin Development Authority (CRBDA) in mapping the land use/cover of Akwa Ibom and Cross River State which this study area is a part of. This scheme has been simplified for the purposes of this study into five land use/cover classes. These are compound farmland, bush fallow, forest, secondary forest and open water. These simplified classes were utilized in order to ease interpretation since the original scheme seemed complicated when considering this study area relative to the entire area that CRBDA used for the classification.

All the image interpretation processes were carried out using Erdas Imagine 9.1 software, while change detection and mapping was completed using the Spatial Analyst extension within ArcGIS 9.2. Erdas Imagine was used due to its robust and advance image analysis functionalities, while the use of ArcGIS was prompted by its flexibility in spatial data handling and analysis. In order to create subset images of the study area prior to actual enhancement and classification procedures, layer stacking and area of interest (AOI) tools were applied to both images. Since the two images were captured during the dry seasons of their respective years, distortions due to weather and season were not taken into consideration. Both images which were relatively cloud-free were subjected to Principal Component Analysis (PCA). This is a spectral enhancement procedure which is often used to compress image data to reduce redundancy. The resultant non-redundant and uncorrelated principal component bands are considered to be easier to interpret than those of the raw images. Supervised classification techniques were applied to derive meaningful classes from the images. Specifically, supervised signature extraction was adopted in conjunction with a maximum likelihood algorithm. Bands 4-3-2 which were found to be very useful in discriminating the land use classes were combined for this purpose. In order to assess the accuracy of the 
classified images, the 1986 classified image was compared to a land cover map published in 1987, while the 2006 classified image was compared to aerial survey data captured in 2002. Furthermore, a field check was also undertaken on the 2006 classified image. A combination of these methods proved very reliable in generating valid land cover categories for the study area.

To achieve the objectives of this study, two forms of spatial analyses were undertaken: area calculation of the land use/cover for each year and post-classification change detection. While area calculation of the land use/ cover for each year involved comparison of the land use classification statistics derived from the classified images, the post-classification change detection was an area-specific change detection procedure (point-by-point). With these two techniques, information on the nature, location, magnitude, trend and rate of change were highlighted. This point-by-point method seems to be superior to other change detection techniques within image analysis systems. It also helped to maintain a finer control over the data sets [17], and offered greater flexibility in generating related classes of change [18]. After the two images were classified and change detection carried out, the actual cartographic production of the land use/cover maps and generation of statistics for inventory was completed using ArcGIS 9.2. This was also used in performing all the GIS related query and analyses.

\section{Findings}

The data collected were analyzed and discussion of findings made in the light of the two main issues the work sought to address. The socio-economic characteristics of the respondents which were acquired during the social survey served as a background for understanding the changes in land cover within the study period. Information on the socio-economic characteristics of the respondents were collected on household basis, but aggregated at the local government level. This level of detail became very necessary since the different land use decisions and activities which feedback on the land cover to induce change takes place at the level of household. Also, since the major land tenure system is free-holding, it is important to understand what transpires regarding land use decisions at the individual household level. The result of the social survey which revealed that, 85 percent of the respondents were males is an indication that the household heads were not only dominated by the male folk but it also implied that land issues were mainly the preserve of the male folk. The study further revealed that 63 percent of the respondents were married while the age bracket of respondents revealed that 50 percent were between the ages of 46 and 59 years. This depicts a very active population and consequently gave clue to the level of utilization of land and land related resources. Information was also obtained on the occupational activities in the study area. Occupation indicated the means of livelihood of the people and the study revealed that 58 percent of the population takes to farming as a major occupation, while 42 percent was distributed between the public service and the business sectors. In terms of yearly income, 65 percent earned less than $\$ 300$ (\#48000) while 35 percent earned between $\$ 300$ and $\$ 800$ (\#48000 and \#128000). The size of each household was also high. The findings showed that 77 percent of the households had 5 persons and above.

\section{Identification of Land Cover Types in Ibiono Ibom LGA}

From the result of the image classification, analysis and change detection, five land cover classes were identified as forest, secondary forest, bush fallow, compound farmland and open water.

\subsection{Compound Farmland}

This form of land cover occupies a significant portion of the study area. It covered a total land area of 6750 hectares in 1986 with an increase of 15 hectares in 2006. It is distributed all over the study area. Compound farmland has about 21 percent of the study area and was second after bush fallow another agricultural land cover type. Compound farmland was characterized by annual farming with scattered trees including oil palm, mango, cocoa and pawpaw. Crops planted include maize, plantain, yam, banana, cassava and sweet potato. The method of land preparation here is by slash and burn (Plate 1). The system of agriculture here is traditionally subsistence with the use of indigenous knowledge and crude implements in most aspects of the farm work.

\subsection{Bush Fallowing}

This is the most dominant form of land cover in the area. In 1986, there was a total of 21923.33 hectares under bush fallow, but by 2006 it had reduced by 680.33 hectares. Like the compound farmland, this cover type is 


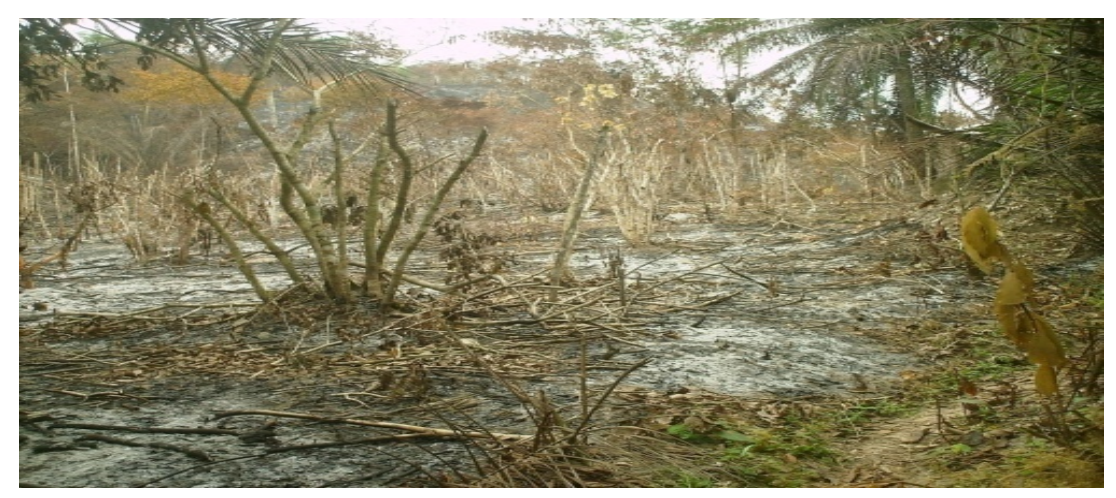

Plate 1. Slash and burn mode of land preparation within compound farmland cover.

found in most places in the study area. There were two types of land cover. The first resulted when the original natural forest has been cleared leaving fields/forest rotation with $1-3$ periods of cropping. Fallow periods ranged from 5 - 15 years. The vegetation is characterized by mosaic of fields, scrub and secondary forest. The second category is field/bush rotation with period of rotation not exceeding 5 years. Some crops that are planted include yam (Diascorea spp.), cassava (Manihot esculenta), cocoyams, cucurbits and maize (Zea mays). Agriculture mostly occurs at subsistence level. Due to the difficulties of distinguishing these two subgroups on the satellite image, they were simply treated as bush fallow and it typically looks like the image presented in Plate 2.

\subsection{Secondary Forest}

Secondary forest vegetation is predominant in northeastern part of the study area. It is made up of a mosaic of primary and secondary forests, scrub and fields including areas of shifting cultivation. Crops planted include yam (Diascorea spp.) cassava (Manihot esculenta), cocoyams, cucurbits and maize (Zea mays). Secondary forest covers a total area of 663.28 hectares in the area.

\subsection{Forest}

This is found close to watercourses such as the Etuep, Duem, Iyere and Ikpa rivers among others, and covers a total of 663 hectares. It is made up of a mosaic of grass plains, palms, swamps, scrub and forest on waterlogged and seasonally flooded soils. In this land cover type are also dense aquatic herbaceous layers, mostly on seasonally flooded soils. Rice, Cyperus, Echniochloa, Panicum and Phragmites are grown. It is found in tiny patches around northern and northeastern parts of Ibiono Ibom LGA. Plants include Elaeis guneensis, Leea guineensis, Mitragyna ciliate and Raphia hookeri.

\subsection{Open Water}

This is the area in which there are large bodies of water big enough to be captured on the satellite image. In this regard, the Cross River passes through a very small portion of the northeastern flank. It covered a total of 92 hectares in 1986.

\section{The Rate, Magnitude and Pattern of Land Cover Change}

After the satellite image processing, change detection analyses were carried out. The first was the comparison of the land cover statistics between the base year 1986 and year 2006 and the second was the actual topological overlay. From the change statistics generated (Table 1); it is observed that secondary forest has increased by 242 hectares between 1986 and 2006. In terms of the rate of change, the analysis further revealed an increase of 12.12 hectares per year. The current trend of rural-urban migration is cited as the major reason for forest rejuvenation in this area. Consequently, there is a scenario of serious reduction in the labor force especially in Ikot Esidem, Idoro, Afua, Ikpanya and Ntan Mbat culminating in an increase in secondary forest. Although a general global trend indicates deforestation, micro-scale studies such as this revealed the true position regarding this particular study area. 


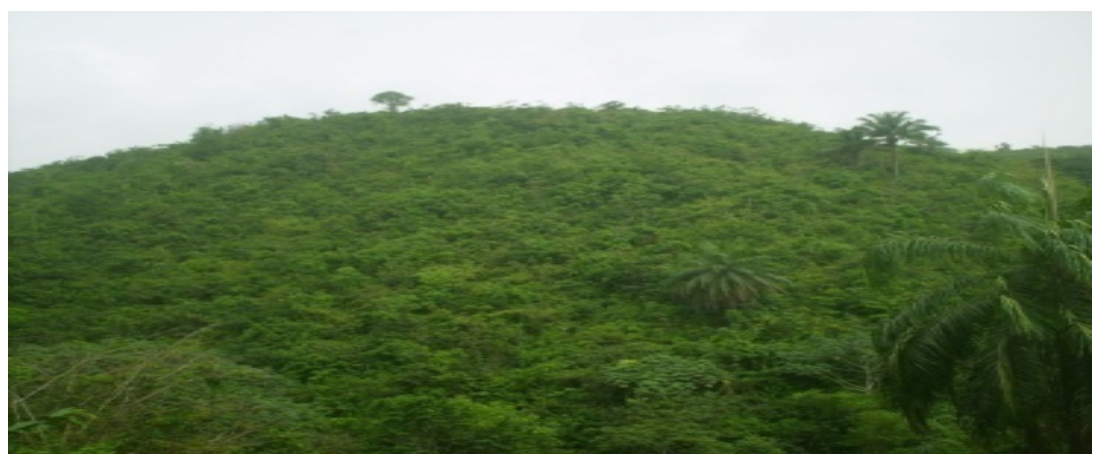

Plate 2. Bush fallow land cover in Ibiono Ibom LGA.

Table 1. Land Cover change statistics between 1986 and 2006.

\begin{tabular}{ccccccc}
\hline Land Use Classes & 1986 (ha) & 2006 (ha) & Change (ha) & Change (\%) & Change/yr (ha) & $\begin{array}{c}\text { Direction of } \\
\text { Change }\end{array}$ \\
\hline Secondary Forest & 2892.34 & 3134.66 & 242.32 & 20.14 & 12.12 & Increase \\
Forest & 663.28 & 922.09 & 258.81 & 21.76 & 12.94 & Increase \\
Compound Farmland & 6750.89 & 6765.90 & 15.01 & 1.00 & 0.75 & Increase \\
Bush Fallow & 21923.33 & 21243.00 & 680.33 & 56.55 & 34.02 & Decrease \\
Open Water & 92.27 & 98.85 & 6.58 & 0.55 & 0.33 & Increase \\
Total & 32229.84 & 32229.84 & 1203.05 & 100 & 60.16 & \\
\hline
\end{tabular}

Ekpa (2012).

Forest covered a total of 663.28 hectares in 1986 and by 2006; the forest area has increased by 258.81 hectares at the rate of 12.94 percent hectares per year. Forest represents about 2 percent of the total land cover in the area. This means that the forest cover within the study area is small relatively. The forest represents the relics of the original tropical rain forest. Being the relics, the findings revealed that they were conserved and no cultivation was done at those areas. The reason was that such forest remains were considered as sacred groves. This is the major reason why it is very stable and experienced increase in size. The earlier reason cited for the growth in secondary forest is also true of the forest cover type in that area. Figure 1 reflects the land cover change between 1986 and 2006 as shown in the Table 1 and Table 2.

Compound farmland has witnessed an increase from 6750.89 hectares in 1986 to 6765.90 hectares in 2006. The magnitude of change here is 15.01 hectares within the study period while the rate of change per year is 0.75 hectares representing only 1 percent of the total change. In terms of bush fallow, there was a reduction in the area of land cover by 680.33 hectares with the rate of change being 34.02 percent per year. This is not a surprise since in the area; extensive system of agriculture is gradually being replaced by intensive cultivation due to population pressure. There is also an increase in the area of open water from 92.27 hectares in 1986 to 98.85 hectares in 2006. This is in line with global trend of increase in water bodies resulting in the submerging of farmlands and settlement areas. In the study area, the problem has not reached such an alarming rate. Table 2 indicates the nature of change in the land cover. In this regard, a total of 6791.08 hectares of the area witnessed reduction while areas of increase and no change were 21614 hectares and 3824 hectares representing 78.70 and 10.07 percent respectively. The areas covered by forest and compound farmland have been the most stable over the study period.

\section{The Direct and Underlying Causes of Land Cover Change}

The drivers of land cover change were classified under: 1) underlying and 2) direct factors. In terms of the underlying drivers of land cover change in the area, it was observed that the most important driver in this regard was the socio-economic characteristics. For instance, the level of the application of the needed inputs for sustainable agriculture and farm management practices has been very low. This is however blamed on poverty. Also, income level, household size and mode of land preparation are other limiting factors to the use of agricultural 
Table 2. Change highlight between 1986 and 2006.

\begin{tabular}{ccc}
\hline Nature of Change & Area (ha) & Percentage \\
\hline Decreased & 6791.08 & 11.23 \\
Increased & 21614.5 & 78.70 \\
Unchanged & 3824.26 & 10.07 \\
& 32201.27 & 100 \\
\hline
\end{tabular}

Ekpa (2012).

innovations, buying improved varieties and acquiring marginal cost for inputs. Income in the area has been incredibly low with over 65 percent of households earning less than $\$ 300$ per annum. As a result of this low income, it may not be immediately conceivable the idea of proper crop and soil husbandry which would have helped stem the tide of unnecessary change in the land cover. Such proper soil and crop husbandry would have helped to concentrate cultivation in the same plots year after year without recourse to expansion. Large family sizes also suggest agricultural expansion and therefore act as underlying drivers that induce land cover change. With many people to feed in a household, the drive to cultivate an extra plot becomes expedient thereby acting as a remote cause of land cover change.

Population growth also induced agricultural intensification by increasing the scarcity of land relative to labour input per unit of land. Growth in population is induced by both natural increase and immigration. These two processes have different and distinctive effects on outcomes of land cover change [19]. Gradual natural increase might result in gradual increase of agricultural intensification and production on existing individual farm holdings. This is because this process will result in bringing new lands under cultivation as well as establish new settlements and related infrastructure. Such factors may lead to acceleration in land cover change. In the study area, the above scenario is common. The social survey conducted revealed that $75 \%$ of the households investigated recorded over 6 new births in their families between 1986 and 2006 pointing to the household population enlargement. A composite of this gives an aggregate at the community level. Looking at the issue from the perspective of the national population headcount, it is seen that in 1986, the population of Ibiono Ibom LGA was little above 113,000 persons, but in 2006, the population had increased to 188,605 persons [20]. In a population that solely depends on land, any increase in population ultimately translates to pressure on the land, hence land cover change. However, the increased in population and corresponding increased in land cover change was facilitated by the 34 percent decrease in bush fallow system as can be observed in Figure 2 and Figure 3 respectively. The most important proximate driver of land cover change in the area is agricultural increase. Factors that encourage agricultural increase in the area include poor yield, poor soil fertility, reduced fallow period, improper agricultural extension services and population pressure. From the social survey carried out, most households generally depend on the natural means of soil nutrient replenishment and this requires that the fallow period be long enough for the land to recover. However, where pressure from the large household sizes set in, the fallow period is reduced and coupled with the low yield, the farmers are left with no alternatives than to increase the farm size. At Ikot Esidem community, the swamps were used for the cultivation of okro in the dry season.

\section{Conclusions and Recommendations}

From the findings, five major land cover classes were identified in the study area. These classes are forests, secondary forests, bush fallow, compound farmland and open water. Of these five land cover categories, bush fallow had a decrease of about 680.33 hectares with annual rate of decrease of 34.02 hectares per year. There have been significant gains in the category of compound farmlands on account of agriculture. In terms of the magnitude of change, a total of 6791.08 hectares of the area witnessed reduction while areas of increase and little change were 21,614 hectares and 3824 hectares representing 78.70 percent and 10.07 percent respectively. The land cover change result has revealed that the most stable of the land covers are the forests and open water, while secondary forest, bush fallow and compound farmland have been prone to changes. From the findings made, it was discovered that the land cover of the area has witnessed significant conversion and modification much of which were at variance with the development efforts of government. In this regard, the related government agencies should, as a matter of policy embark on data acquisition, analysis of land use and land cover 


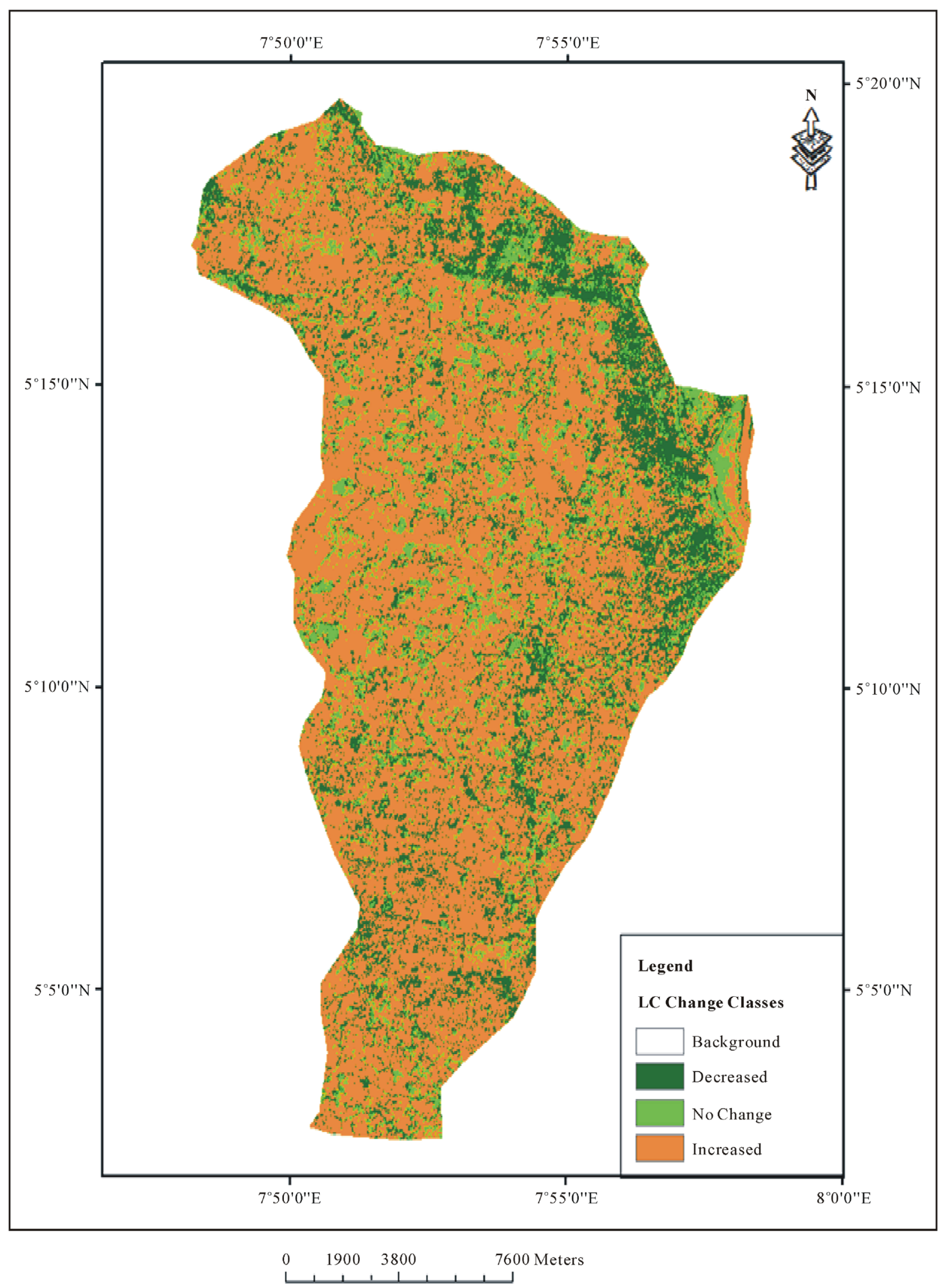

Figure 1. Ibiono Ibom LGA showing land cover (1986-2006). 


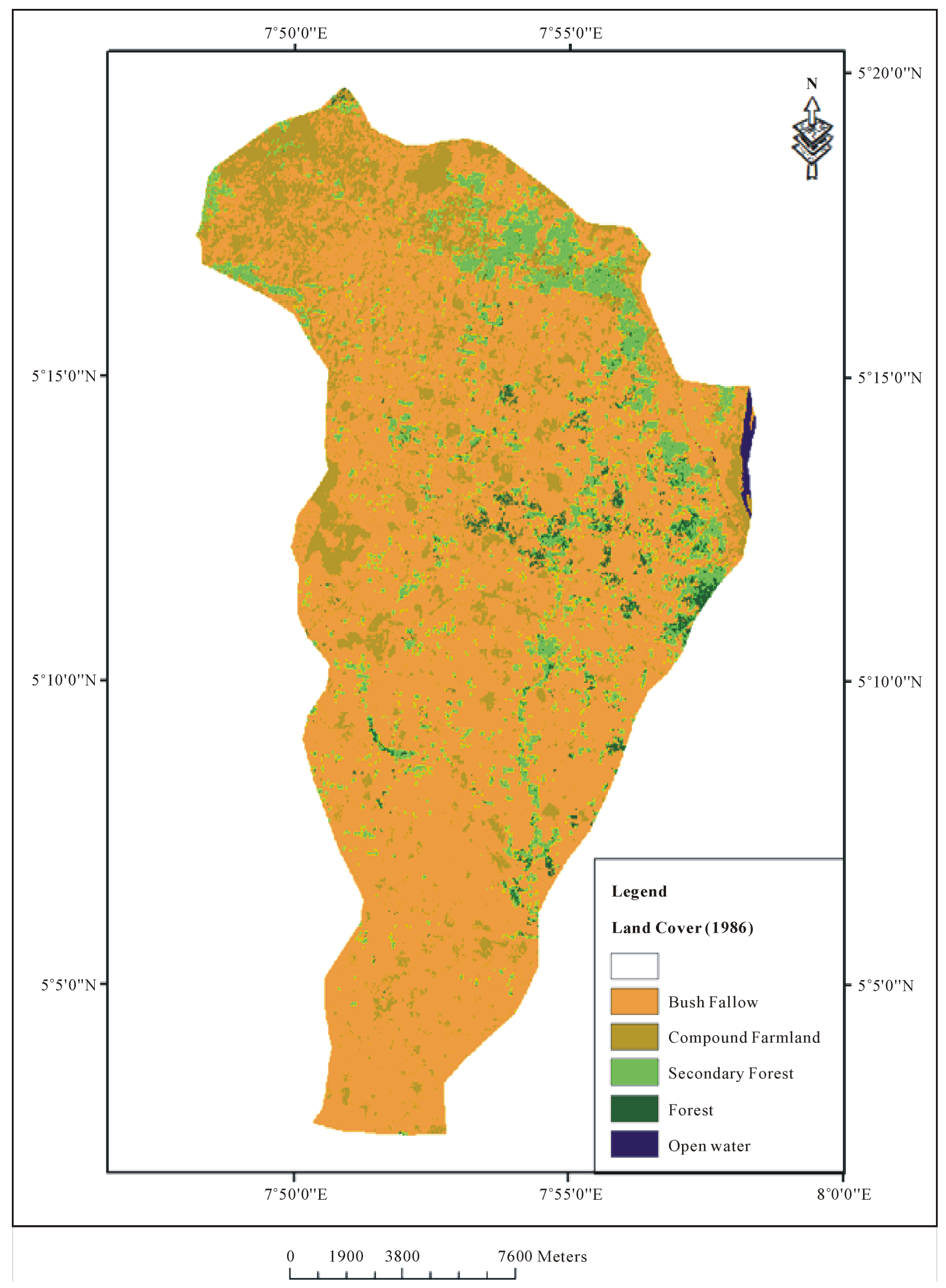

Figure 2. Ibiono Ibom LGA showing land cover (1986). 


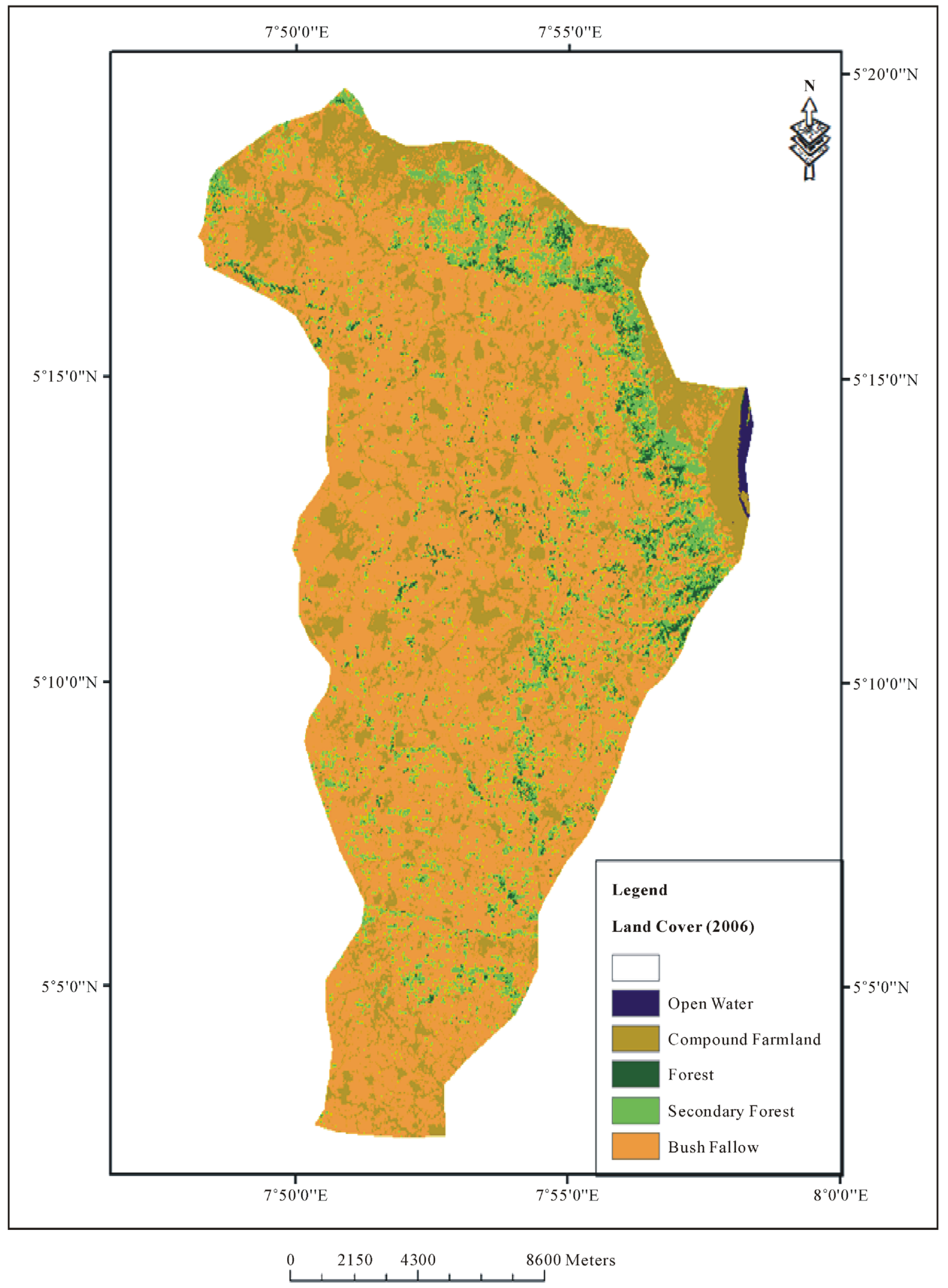

Figure 3. Ibiono Ibom LGA showing land cover (2006). 
change so as to detect the changes that have taken place over time. Such information should then be used to support land use related decisions as well as acting as the basis for planning. Also, it has been recorded that the major underlying cause of land cover change in the study area is the socio-economic factor. Socio-economic issues necessarily involve means of livelihood including occupation, income and household size.

The research has revealed that a greater proportion of the occupation is land based. This implies that at the moment, there is so much pressure on the land. Consequently, it is recommended that the rural development efforts should be transformational rather than the current remedial approach which, for instance, gives fertilizer and agricultural extension services, much of which encouraged continued pressure on the land. Thus, if the entire Local Government Area is transformed by the provision of infrastructures and social amenities, presumably it could ease off some pressure on land since some people are likely to take to the alternative openings like welding, plumbing and furniture. The main land management strategy adopted here is the rotational bush fallow system. This has failed to guarantee sustainable use of land cover more so now that the length of fallow period has reduced. Increased rate of land fragmentation and multiple holdings were recorded in the study area. These have triggered off serious land management problems. The prospects for improved food production therefore seem bleak unless these issues are resolved.

\section{References}

[1] Ituen, U.J., Whyatt, J.D., Blackburn, G.A. and Inyang, I.B. (2008) Land Use/Cover Change and Agricultural Practices in the Tropical Environment of Northern Akwa Ibom State, Nigeria. 14th International Symposium on Implementation of Landscape Ecology in New and Changing Conditions, Stara Lesna, 4-7 October 2006.

[2] Khadka, M.B. (1997) Spatial Assessment of Human Disturbances on the Middle Hills Forest of Nepal: A Case Study of Shivapuri Watershed and Wildlife Reserve. ITC Journal, 2, 170-171.

[3] Foody, G.M. and Curran, P.J. (1994) Estimation of Tropical Forest Extent and Regeneration Stage Using Remotely Sensed Data. Journal of Biogeography, 21, 223-244. http://dx.doi.org/10.2307/2845527.

[4] Anderson, C. (1995) Land Use/Land Cover Mapping in Mongolia. Remote Sensing Information from Swedish Space Corporation, 26.

[5] Adedire, M.D. (2005) Gender Perception on Constraints affecting Agroforestry Practices. http://docdrive.com/pdfs/medwelljournals/aj/2008/375-381.pdf

[6] Dale, V.H., Brown, S., Hacuber, R.A., Hobbs, N.T., Hurtly, N., Naiman, R.J., Reibsame, W.E., Turner, M.G. and Valone, T.J. (2000) Ecological Principles and Guidelines for Managing the Use of Land. Ecological Application, 10, 639670.

[7] Adeniyi, P.O. and Omojola, A. (1999) Land Use and Land Cover Change in the Sokoto-Rima Basin of Northwest Nigeria Based on Archival Remote Sensing and GIS Techniques. In: Adeniyi, P.O., Ed., Geoinformation Technology Applications for Resource and Environmental Management in Africa, African Association of the Environment (AARSE), Wura-Kay Prints, Lagos, 120-129.

[8] Liu, J., Zhan, J. and Deng, X. (2005) Spatio-Temporal Patterns and Driving Forces of Urban Land Expansion in China during the Economic Reform Era. AMBIO. A Journal of the Human Environment, Royal Swedish Academy of Science, 447, 450-455. http://ambio.allenpress.com

[9] Borma, G.A. (1999) Change in Vegetation Cover in East Timor, 1989-1999. www.onlinelibrary.wiley.com/doi/10.1111/narf.2004.28.issue-1/issuetoc

[10] Food and Agriculture Organization (1997) State of the World's Forests. United Nations, Rome.

[11] Adedire, M.D., Bolaji, G.A. and Martins, O. (2000) Effects of Deforestation on Water Quality and Sedimentation: The Nigeria Experience. Journal of Tropical Forest Resources, 16, 20-29.

[12] Omiyale, O. (2001) Impacts of Encroachment on Sustainable Development. Journal of Tropical Forest Resources, 17, 2, 19-27.

[13] Adetula, T. (2001) Encroachment and Its Impacts on Forestry Development: A Case Study of Edo State. Journal of Tropical Forest Resources, 17, 44-61.

[14] Ekpo, J.U. (2001) Forestry Policy Direction in Akwa Ibom State. In: Forestry and Sustainable Development, Proceedings of the 1st Workshop of the Forestry Association of Nigeria, Uyo, 10-11 April 2001, 56-64.

[15] Udo, E.S., Udofia, S.J. and Okwara, U.O. (2005) Public Awareness of Impacts of Deforestation in Ohafia Local Government of Abia State. Department of Forestry and Wildlife, University of Uyo, Uyo.

[16] Muller, D. and Zeller, M. (2002) Land Use Dynamics in the Central Highlands of Vietnam: A Spatial Model Combin- 
ing Village Survey with Satellite Imagery Interpretation. Agricultural Economics, 27, 333-354.

www.elservier.com/locate/agecon

http://dx.doi.org/10.1111/j.1574-0862.2002.tb00124.x

[17] Jakubauskas, M.E., Lulla, K.P. and Mausel, P.W. (1990) Assessment of Vegetation Change in a Fire-Altered Forest Landscape. Photogrammetric Engineering and Remote Sensing, 56, 371-377.

[18] Ekpa, J.J. (2012) Effects of Land Cover Change on the Socioeconomic Life of the People of Ibiono Ibom, Akwa Ibom State. Unpublished M.Sc. Dissertation, University of Uyo, Uyo.

[19] Muller, D. (2003) Land Use Change in the Central Highlands of Vietnam: A Spatial Model Combining Satellite Imagery Interpretation with Village Survey Data. Doctoral Dissertation, Gottingen University, Gottingen.

[20] National Population Commission (2006) Population Figure of Ibiono Ibom. 
Scientific Research Publishing (SCIRP) is one of the largest Open Access journal publishers. It is currently publishing more than 200 open access, online, peer-reviewed journals covering a wide range of academic disciplines. SCIRP serves the worldwide academic communities and contributes to the progress and application of science with its publication.

Other selected journals from SCIRP are listed as below. Submit your manuscript to us via either submit@scirp.org or Online Submission Portal.
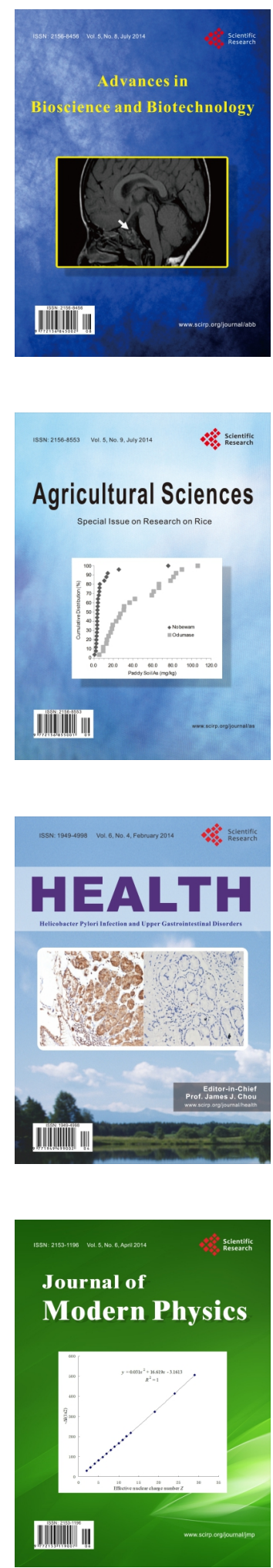
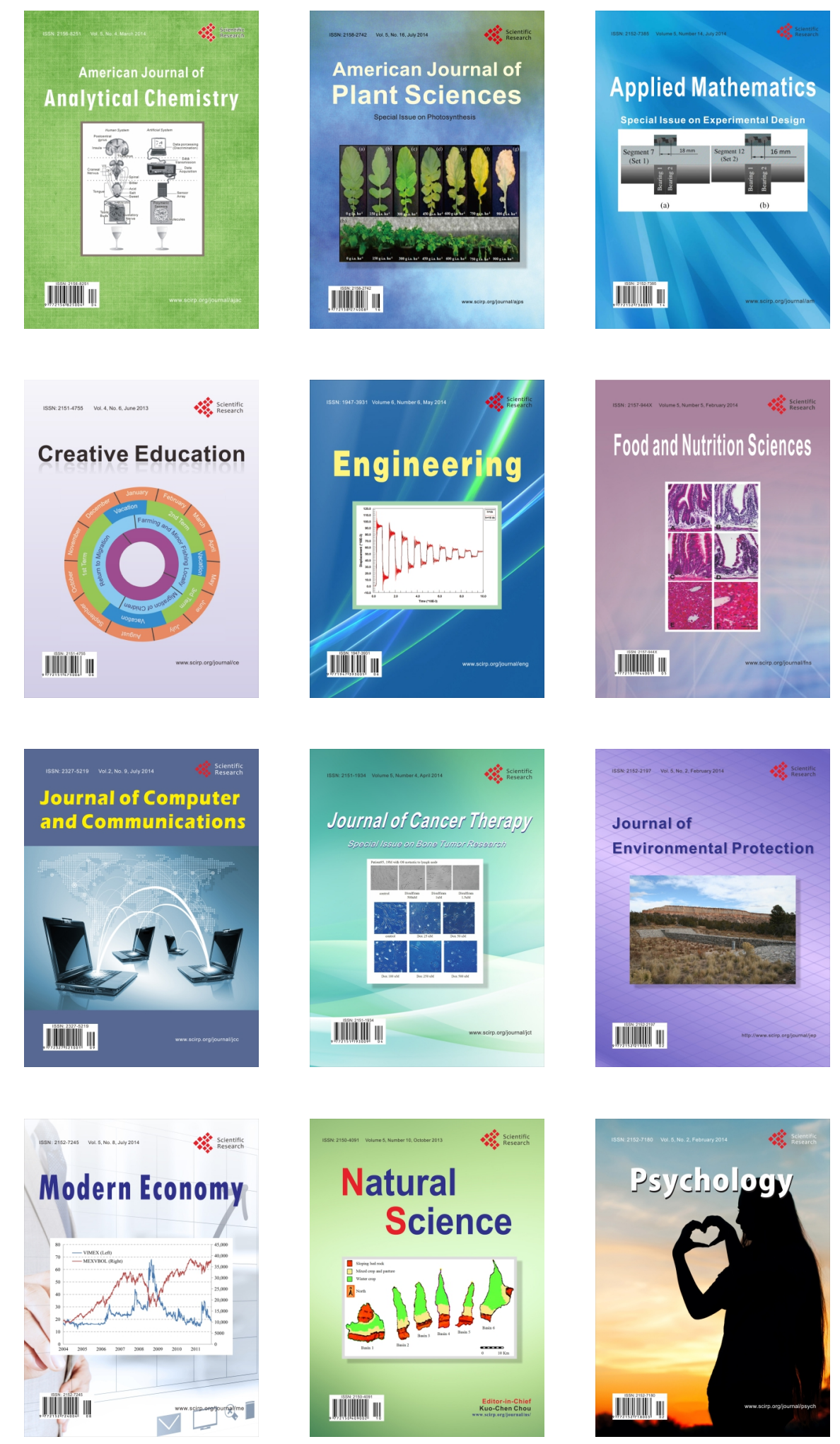